\title{
A framework for IS200, 16S rRNA gene and plasmid-profile analysis in Salmonella serogroup D1
}

\author{
J. STANLEY, N. POWELL, C. JONES and A. P. BURNENS*
}

NCTC Molecular Genetics Unit, Central Public Health Laboratory, Public Health Laboratory Service, 61 Colindale Avenue, London NW9 $5 H T$ and * Swiss National Reference Laboratory for Foodborne Disease, Institute for Veterinary Bacteriology, University of Berne, Langass-Strasse 122, CH-3012 Berne, Switzerland

\begin{abstract}
Summary. Chromosomal fingerprinting of the type strains of serotypes of Salmonella Oserogroup D1 with the DNA insertion sequence IS200 generated patterns which were either serotype-specific (e.g., Typhi), or conserved among groups of related serotypes (e.g., Dublin, Rostock and certain phage types of Enteritidis). The number of IS200 copies varied considerably, and the IS200 patterns of type strains of serotypes associated with systemic infections in man were specific and suitable for identifying strains within those serotypes. Polymorphism at $16 \mathrm{~S}$ rRNA gene loci was examined among type strains and $1116 \mathrm{~S}$ rRNA gene profiles were characterised. The most prevalent of these was conserved among type strains of 11 serotypes, and the next most prevalent among type strains of nine serotypes; together, they encompassed 15 unique IS200 profiles. The distribution and mol. wts of plasmids carrying spv $B C$ (virulence) genes could be directly related to certain chromosomal genotypes defined by IS200 patterns. The presence of virulence plasmids in serotypes Lomalinda, Antarctica and Wangata is reported for the first time. Comparison of $16 \mathrm{~S}$ rRNA gene profiles and IS200 patterns provides a definition of genotype that is applicable to epidemiological studies of various group D1 serotypes and should prove particularly useful for those lacking plasmid DNA.
\end{abstract}

\section{Introduction}

The cell-surface antigen profiles of salmonellae are so diverse that serotyping has, historically, provided a reliable phenotypic method for their differentiation. In the diagnostic scheme of Kauffmann and White, $>2300$ serotypes of Salmonella are distinguished. ${ }^{1}$ Clinically or epidemiologically important serotypes, such as Typhi or Enteritidis, can be subtyped by serotype-specific phage typing. However, for most other salmonella serotypes phenotypic subtyping is not available; hence, the development of chromosomal fingerprinting by a common methodology would prove enormously valuable. Ribosomal RNA genes have provided one such probe. ${ }^{2}$ The profile of the DNA insertion sequence IS $200^{3,4}$ also provides fingerprints of salmonella chromosomes that reproducibly discriminate epidemiological clonality in salmonella serotypes, if the copy number is sufficiently high. ${ }^{5}$

Certain serotypes of Salmonella contain high-mol.wt plasmids, related by DNA homology and restriction endonuclease fingerprinting, that contain a common "virulence region". ${ }^{6.7}$ Six $s p v$ (salmonella $p$ lasmid $v$ irulence) genes have been characterised to the nucleotide sequence level; one, $s p v C$, has a clearly demonstrable role in virulence for mice. ${ }^{8}$ However,

Received 19 Nov. 1993; revised version accepted 1 March 1994. virulence plasmids are absent from some other important serotypes of Salmonella. ${ }^{9,10}$

We have compared restriction fragment length polymorphism (RFLP) at IS200 and 16S rRNA gene loci, and examined the presence of virulence plasmids in type strains of serotypes of Salmonella of Kauffmann-White O-serogroup D1. The objective of this study was to provide a necessary background for the rapid molecular definition of genotype in epidemiological studies.

\section{Materials and methods}

\section{Bacteria}

Strains of Salmonella used in this study ${ }^{11.12}$ are listed in table I. Purity was checked on blood agar plates before growth in Luria-Bertani broth for isolation of DNA. Stock cultures were maintained on Dorset's egg slopes.

\section{$D N A$ isolation, probes and hybridisation}

Preparation of intra-genic probes for IS200 and the $16 \mathrm{~S} r r n$ gene, labelling with 16-dUTP-biotin and hybridisation conditions have been described previously. ${ }^{5}$ Plasmid DNA was isolated by the method of Kado and $\mathrm{Liu}^{13}$ and genomic DNA by the method 
Table I. Type strains of Salmonella of O-serogroup D1 used

\begin{tabular}{|c|c|c|c|c|c|}
\hline Serotype & $\begin{array}{c}\text { Strain } \\
\text { number }{ }^{11}\end{array}$ & $\mathrm{O}$ antigens & $\begin{array}{c}\mathrm{H} \text { antigen } \\
\text { phase } 1\end{array}$ & $\begin{array}{c}\mathrm{H} \text { antigen } \\
\text { phase } 2\end{array}$ & $\begin{array}{l}\text { Place and date } \\
\text { of isolation }^{11}\end{array}$ \\
\hline Miami & NCTC 7112 & $1,9,12$ & a & 1,5 & Kentucky 1946 \\
\hline Saarbruecken & NCTC 9904 & $1,9,12$ & a & 1,7 & Copenhagen 1956 \\
\hline Lomalinda & NCTC 6705 & $1,9,12$ & a & $\mathrm{e}, \mathrm{n}, \mathrm{x}$ & Kentucky 1944 \\
\hline Durban & NCTC 6235 & 9,12 & a & $\mathrm{e}, \mathrm{n}, z_{15}$ & Onderstepoort 1941 \\
\hline Onarimon & NCTC 6047 & $1,9,12$ & $\mathrm{~b}$ & 1,2 & Tokyo 1940 \\
\hline Alabama & NCTC 9868 & 9,12 & $\mathrm{c}$ & $\mathrm{e}, \mathrm{n}, \mathrm{z}_{15}$ & Copenhagen 1956 \\
\hline Typhi & NCTC 8385 & $9,12[\mathrm{Vi}]$ & $\mathrm{d}$ & - & Colindale 1953 \\
\hline Ndolo & NCTC 8700 & $1,9,12$ & d & 1,5 & Copenhagen 1950 \\
\hline Zega & NCTC 8243 & 9,12 & $\mathrm{~d}$ & $\mathrm{z}_{6}$ & Copenhagen 1952 \\
\hline Eastbourne & NCTC 5771 & $1,9,12$ & $\mathrm{e}, \mathrm{h}$ & 1,5 & Copenhagen 1939 \\
\hline Israel & NCTC 9881 & 9,12 & $\mathrm{e}, \mathrm{h}$ & $\mathrm{e}, \mathrm{n}, \mathrm{z}_{15}$ & Copenhagen 1956 \\
\hline Berta & NCTC 5770 & $1,9,12$ & $\mathrm{f}, \mathrm{g}, \mathrm{t}$ & - & Copenhagen 1951 \\
\hline Enteritidis & LEP $-E 2109^{12}$ & $1,9,12$ & {$[\mathrm{f}], \mathrm{g}, \mathrm{m},[\mathrm{p}]$} & {$[1,7]$} & UK 1967 , phage type 11 \\
\hline Enteritidis & LEP $-E 2468^{12}$ & $1,9,12$ & {$[\mathrm{f}], \mathrm{g}, \mathrm{m},[\mathrm{p}]$} & {$[1,7]$} & UK 1968 , phage type 8 \\
\hline Enteritidis & LEP--E $2187^{12}$ & $1,9,12$ & {$[\mathrm{f}], \mathrm{g}, \mathrm{m},[\mathrm{p}]$} & {$[1,7]$} & UK 1967 , phage type 4 \\
\hline Blegdam & NCTC 5769 & $1,9,12$ & $\mathrm{~g}, \mathrm{~m}, \mathrm{q}$ & - & Copenhagen 1939 \\
\hline Dublin & NCTC 9676 & $1,9,12$ & $\mathrm{~g}, \mathrm{p}$ & - & UK 1955 \\
\hline Rostock & NCTC 5767 & $1,9,12$ & $\mathrm{~g}, \mathrm{p}, \mathrm{u}$ & - & Copenhagen 1939 \\
\hline Moscow & NCTC 10480 & 9,12 & $\mathrm{~g}, \mathrm{q}$ & - & Colindale 1967 \\
\hline Neasden & NCTC 10545 & 9,12 & $\mathrm{~g}, \mathrm{~s}, \mathrm{t}$ & $e, n, x$ & Colindale 1967 \\
\hline Antarctica & NCTC 11342 & 9,12 & $\mathrm{~g}, \mathrm{z}_{63}$ & - & Colindale 1980 \\
\hline Pensacola & NCTC 6946 & $1,9,12$ & $\mathrm{~m}, \mathrm{t}$ & {$[1,2]$} & Kentucky 1945 \\
\hline Claibornei & NCTC 6587 & $1,9,12$ & $\mathrm{k}$ & 1,5 & Kentucky 1943 \\
\hline Mendoza & NCTC 9888 & 9,12 & $1, v$ & 1,2 & Copenhagen 1956 \\
\hline Panama & NCTC 5774 & $1,9,12$ & $1, \mathrm{v}$ & 1,5 & Copenhagen 1939 \\
\hline Goettingen & NCTC 6258 & 9,12 & $1, v$ & $\mathrm{e}, \mathrm{n}, z_{15}$ & Copenhagen 1941 \\
\hline Daressalaam & NCTC 5773 & $1,9,12$ & $1, w$ & $e, n, x$ & Copenhagen 1939 \\
\hline Napoli & NCTC 6853 & $1,9,12$ & $1, z_{13}$ & $\mathrm{e}, \mathrm{n}, \mathrm{x}$ & Kentucky 1944 \\
\hline Javiana & NCTC 6495 & $1,9,12$ & $1, z_{28}$ & 1,5 & Kentucky 1943 \\
\hline Wangata & NCTC 8276 & $1,9,12$ & $z_{4}, z_{23}$ & {$[1,7]$} & Copenhagen 1953 \\
\hline Portland & NCTC 9907 & 9,12 & $z_{10}$ & 1,5 & Copenhagen 1956 \\
\hline Pullorum & NCTC 5776 & $1,9,12$ & - & - & Copenhagen 1939 \\
\hline
\end{tabular}

of Wilson. ${ }^{14}$ Small amounts $(3 \mu \mathrm{g})$ of genomic DNA were digested with PstI, PvuII or BglII for determination of IS 200 pattern, or with PvuII, PstI or SmaI for 16S rRNA gene profile. These enzymes lack restriction sites within the corresponding DNA probe sequences. ${ }^{15,16}$ The $\operatorname{sp} v B C$ virulence gene probe, a $4 \cdot 1-\mathrm{kbp} E c o$ RI fragment of plasmid pIP $1367,{ }^{6}$ was separated by electrophoresis in low-melting-point agarose and labelled by random priming.

\section{Results}

\section{IS200 patterns}

The distribution of IS200 was investigated principally in genomic Southern blots made with Pst $\mathrm{I}$, such as those shown in fig. 1. "IS200 bands", as discussed below, should correspond to insertion sites carried on PstI fragments. Simple conserved features were found in 10 strains, including the type strains of seven serotypes sharing the phase-1 flagellar antigen "g", and serotype Pullorum. Except for serotype Berta, these type strains possessed two IS200 bands and shared a $4 \cdot 5-\mathrm{kbp}$ IS200 band (see fig. 2). There were two subgroups, one of which contained IS200 bands of 4.5 and $5.2 \mathrm{kbp}$, and the other of 4.5 and $3.9 \mathrm{kbp}$. The former subgroup comprised the type strains of serotypes Enteritidis (PT4), Blegdam, Moscow and Antarctica, each of which showed the
16S rRNA gene profile D-RI (see below and table II). It also included the type strain of the non-motile, nonflagellate serotype Pullorum. The latter subgroup comprised type strains of serotypes Enteritidis (PT11), Dublin and Rostock, each of which showed a $16 \mathrm{~S}$ rRNA gene profile termed D-RII (see below and table II). The type strain of serotype Enteritidis PT8 had a distinct IS200 profile, but shared the 16S rRNA gene profile termed D-RI (see below) of Enteritidis PT4.

The other IS200 profiles found among type strains of serogroup D1 were diverse, and unique profiles were associated with many of them. Nonetheless, certain bands were conserved among serotypes. In ascending order of size, a $2 \cdot 1-\mathrm{kbp}$ band was observed in four serotypes, and a $2 \cdot 2-\mathrm{kbp}$ band in five serotypes. The 3.9-kbp band (see above) occurring in serotypes Enteritidis (PT11), Dublin, Rostock and Berta was also observed in serotype Lomalinda. The $4 \cdot 5-\mathrm{kbp}$ band conserved among the serotypes with " $\mathrm{g}$ " flagellar antigen occurred also in serotype Wangata. Similarly, a $4 \cdot 8-\mathrm{kbp}$ band occurred in four serotypes and a $6 \cdot 7-\mathrm{kbp}$ band in three serotypes. High IS200 copy numbers, with unrelated RFLP characteristics, were observed in serotypes Typhi, Lomalinda, Pensacola, Wangata and Portland. Serotypes Israel and Goettingen, which belong to different D1 subgroups but share the flagellar phase- 2 antigen $\left(e, n, z_{15}\right.$ ), had identical IS200 patterns with PstI (fig. 1) PvuII or $B g l$ II. 


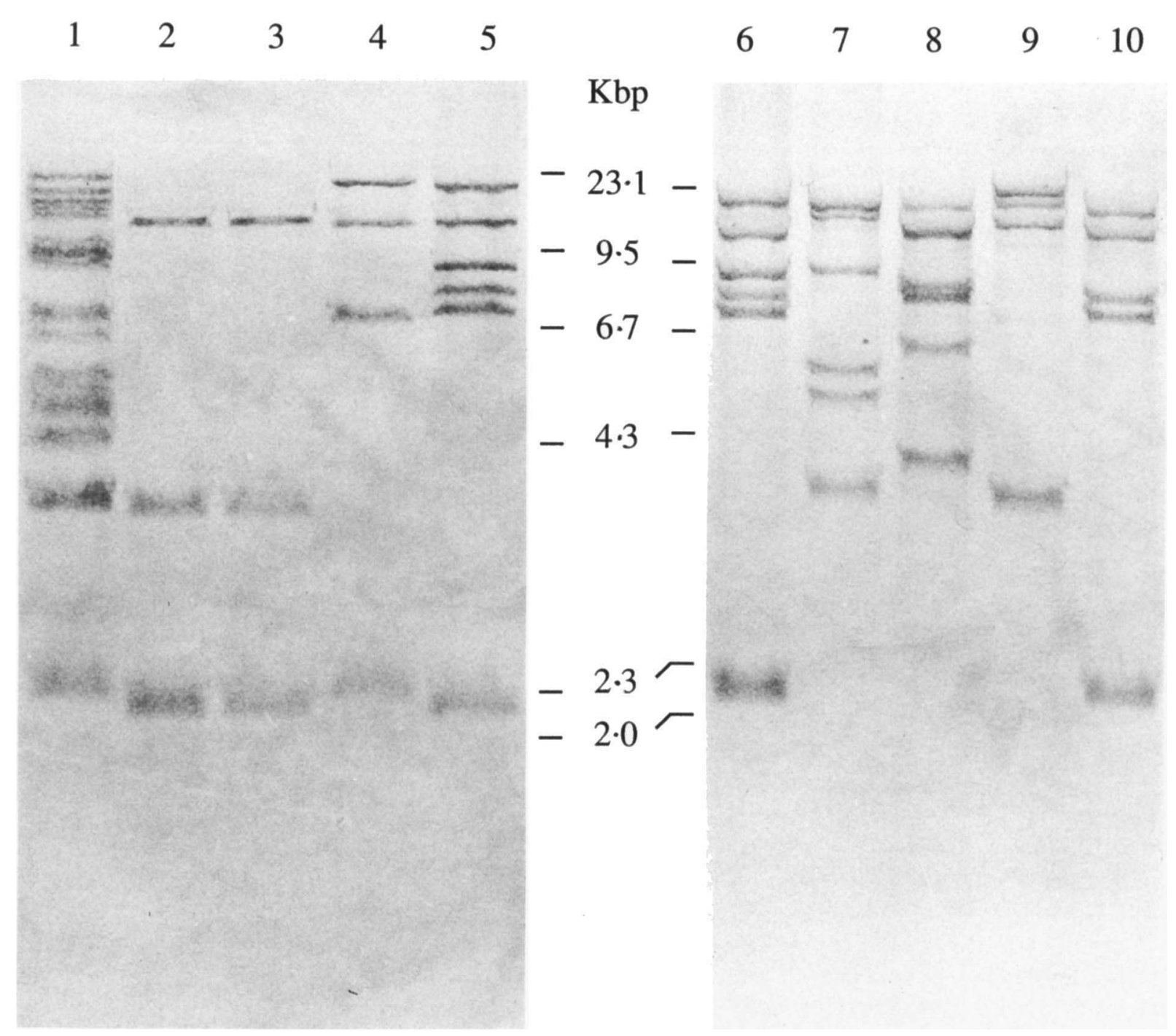

Fig. 1. Examples of IS200 profiles showing genomic Southern blots made with PstI hybridised with 300-bp probe internal to IS200. Lanes show: 1, Pensacola; 2, Israel; 3, Goettingen; 4, Ndolo; 5 and 6, Saarbruecken; 7, Onarimon; 8, Panama; 9, Miami; 10, Durban.

\section{$16 S$ rRNA gene profiles}

Restriction endonuclease $P v u I I$ generated the most discriminatory $16 \mathrm{~S}$ rRNA gene profiles; thus, 11 unique profiles were found among type strains of the 30 group D1 serotypes examined and were identified by the prefix D-R (I-XI). Characteristic examples are shown in fig. 3. With two exceptions, the number of homologous $P v u I I$ fragments was six. Type strains of serotypes Typhi and Lomalinda, which display among the largest numbers (14) of chromosomal IS200 insertions, generated a five-band profile. A PvuII fragment of $9.3 \mathrm{kbp}$ was ubiquitous, whilst fragments of $3.4,6 \cdot 5,9 \cdot 5$ and $c .15 \mathrm{kbp}$ occurred in otherwise diverse profiles.

The commonest profile, D-RI, shared by type strains of 11 serotypes, was distributed throughout serogroup D1 without reference to phase-1 flagellar antigen composition; this group included the type strains of the epidemic phage types (PT4 and PT8) of serotype Enteritidis, as well as serotypes Moscow, Blegdam and Antarctica which also possess the phase-1 flagellar antigen " $g$ ". However, the type strains of serotypes
Miami, Saarbruecken, Ndolo and Goettingen which have other diverse flagellar antigens (see table II) also showed the D-RI profile.

The second commonest profile (D-RII) was conserved among the type strains of nine serotypes, including a phage-type strain (PT11) of serotype Enteritidis, serotype Dublin and serotype Berta. The D-RIII 16S rRNA-gene profile was shown by the type strains of serotypes Napoli and Portland (fig. 3, track 4) and D-RIV by the type strains of serotypes Daressalaam and Neasden, which have the same $(e, n$, $x$ ) phase-2 flagellar antigens (data not shown). Seven other profiles (D-RV-D-RXI) were found in individual type strains only (e.g., fig. 3, tracks 2, 3, 6, 7, 8 and 9). Profile D-RX was observed in serotype Pullorum, which had the same IS200 profile (SeCLI: table II) as the Enteritidis (PT4) group. The overall occurrence of $16 \mathrm{~S}$ rRNA gene profile in relation to IS200 pattern is documented in table II.

\section{Plasmid analysis}

Eighteen strains belonging to 16 serotypes carried 


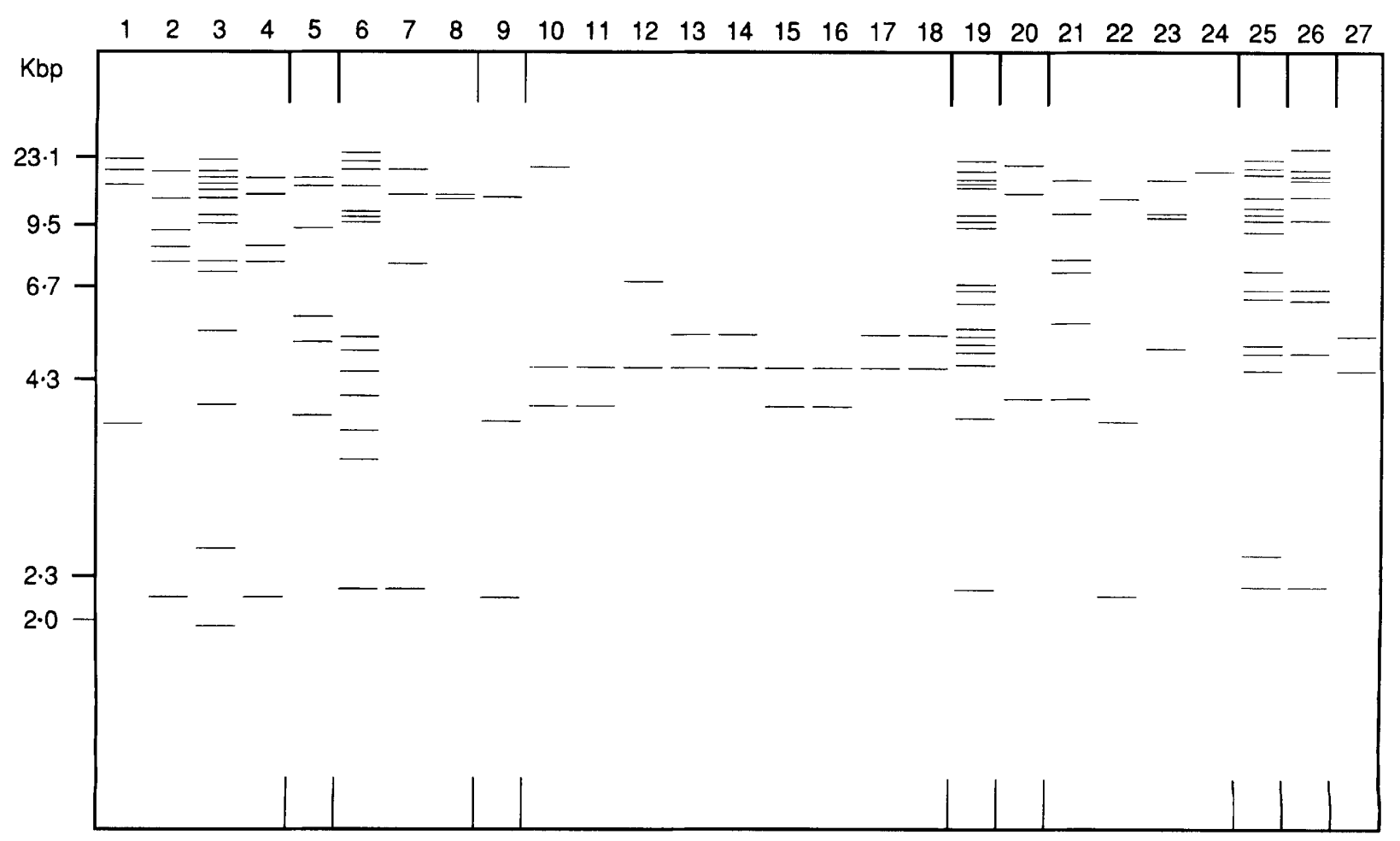

Fig. 2. Diagrammatic representation of IS200 patterns in Salmonella serogroup D1 showing IS 200 bands observed in PstI digests represented for all strains where the element was present. Order of serotypes follows Kauffmann-White scheme subgroupings and lanes show the profiles of: 1, Miami; 2, Saarbruecken; 3, Lomalinda; 4, Durban; 5, Onarimon; 6, Typhi; 7, Ndolo; 8, Zega; 9, Israel; 10, Berta; 11, Enteritidis PT 11; 12, Enteritidis PT8; 13, Enteritidis PT4; 14, Blegdam; 15, Dublin; 16, Rostock; 17, Moscow; 18, Antarctica; 19, Pensacola; 20, Claibornei; 21, Panama; 22, Goettingen; 23, Napoli; 24, Javiana; 25, Wangata; 26, Portland; 27, Pullorum.

plasmids, ranging in size from 1 to $126 \mathrm{MDa}$, the majority of which were $>30 \mathrm{MDa}$ in size. The type strains of four serotypes carried two plasmids; those of 14 other serotypes carried none (table II). None of the plasmids showed any homology with IS200. Eleven plasmids ranging in size from $28 \mathrm{MDa}$ (in serotype Lomalinda) to $59 \mathrm{MDa}$ (in serotype Enteritidis) exhibited homology with the plasmid virulence genes $s p v B C$ (fig. 4A versus $\mathrm{B}$ ) of Typhimurium. These virulence plasmids are reported for the first time for serotypes Lomalinda, Antarctica and Wangata.

\section{Discussion}

A conceptually simple and satisfactory approach to ribotyping ${ }^{2}$ employs PCR-generated intra-genic probes to obtain 16S rRNA gene-specific profiles. ${ }^{5,17}$ In this way, 11 distinct $16 \mathrm{~S}$ rRNA gene profiles were observed among 32 strains in this study. Seven of these were specific to individual serotypes. Two conserved profiles (termed D-RI and D-RII) were found among strains with 15 distinct IS200 patterns, suggesting a common ancestry among these strains. The $16 \mathrm{~S}$ rRNA gene profile D-RIV was shared by serotypes Daressalaam and Neasden, which lacked IS200; this is consistent with their assignment to a different subspecies (subsp. salamae) of Salmonella enterica.

Both IS200 and 16S rRNA gene profiles indicate that there is indeed a close phylogenetic relationship between two subgroups of serotypes forming the " $\mathrm{g}$ " flagellar antigen group. Serotypes Enteritidis (PT11), Dublin and Rostock have one set of identical IS200 and $16 \mathrm{~S}$ rRNA gene profiles whereas serotypes Enteritidis (PT4), Blegdam and Moscow have another. With respect to serotypes Enteritidis (PT11), Dublin and Rostock, multilocus enzyme electrophoresis (MLEE) has demonstrated that certain electrophoretic types (ETs) of serotype Dublin are virtually identical to the most common ET of serotype Enteritidis, and that serotype Rostock too is virtually identical to Dublin. ${ }^{18,19}$ The pattern of conservation of IS200 and 16S rRNA gene profiles in this study is consistent with the suggestion ${ }^{20}$ that the globally predominant ET of serotype Enteritidis resembles the ancestor of serotypes Dublin and Pullorum. Another point of evolutionary interest concerns serotypes Israel and Goettingen, whose identical IS200 profile indicates their common chromosomal genetic origin. These serotypes share the same phase-2, but have different phase-1, flagellar antigens. One, or other, may represent a case of gene-specific evolution to new serotype by horizontal transfer of the $\mathrm{AlC}$ (phase-1 flagellin) gene, a mechanism proposed by Smith et al. ${ }^{18}$

Lam and Roth ${ }^{3}$ noted that each of the five serotypes of Salmonella shown to carry more than six IS200 copies was a mammalian pathogen. In the present study, the type strains of three serotypes with a large number of IS200 bands-Typhi, Lomalinda (NCTC 6705; isolate from a baby with meningitis) and Portland (NCTC 9907; isolate from woman with peritonitis) - were from systemic infections of man, 
Table II. 16S rRNA-gene profiles, IS200 patterns and plasmids of type strains of serotypes of Salmonella of O-serogroup D1

\begin{tabular}{|c|c|c|c|c|}
\hline Serotype & $\begin{array}{c}\text { 16S rRNA gene } \\
\text { profile } \\
\text { (D-R) }\end{array}$ & IS200 pattern & $\begin{array}{l}\text { number of } \\
\text { IS } 200 \text { bands }\end{array}$ & $\begin{array}{l}\text { Plasmid } \\
\text { sizes } \\
(\mathrm{MDa})\end{array}$ \\
\hline Miami & RI & $u$ & 4 & 60 \\
\hline Saarbruecken & RI & $u$ & 6 & $\ldots$ \\
\hline Lomalinda & RVI & $u$ & 14 & $28^{*}$ \\
\hline Durban & $\mathrm{RI}$ & $u$ & 5 & $\ldots$ \\
\hline Onarimon & RII & $u$ & 6 & $\ldots$ \\
\hline Alabama & RIX & $\ldots$ & 0 & 52 \\
\hline Typhi & RXI & $u$ & 14 & $\ldots$ \\
\hline Ndolo & RI & $u$ & 4 & $\ldots$ \\
\hline Zega & RII & $u$ & 2 & $\ldots$ \\
\hline Eastbourne & RVII & $\ldots$ & 0 & 126,34 \\
\hline Israel & RI & $\mathrm{C}$ & 3 & 50,46 \\
\hline Berta & RII & $u$ & 3 & $\ldots$ \\
\hline Enteritidis (PT11) & RII & C: SeCLIII & 2 & $59^{*}$ \\
\hline Enteritidis (PT8) & RI & $\mathrm{C}: \mathrm{SeCLII}$ & 2 & $38^{*}$ \\
\hline Enteritidis (PT4) & RI & $\mathrm{C}: \mathrm{SeCLI}$ & 2 & $38^{*}$ \\
\hline Blegdam & RI & $\mathrm{C}: \mathrm{SeCLI}$ & 2 & $36^{*}$ \\
\hline Dublin & RII & C: SeCLIII & 2 & $50^{*}$ \\
\hline Rostock & RII & C:SeCLIII & 2 & $50^{*}$ \\
\hline Moscow & RI & C: SeCLI & 2 & $38^{*}, 30$ \\
\hline Neasden $\ddagger$ & RIV & $\ldots$ & 0 & $\ldots$ \\
\hline Antarctica & RI & C: SeCLI & 2 & $38^{*}, 26$ \\
\hline Pensacola & RVIII & $u$ & 17 & $\ldots$ \\
\hline Claibornei & RI & $u$ & 3 & 52 \\
\hline Mendoza & RII & $\ldots$ & 0 & $\ldots$ \\
\hline Panama & RV & $u$ & 6 & $\ldots$ \\
\hline Goettingen & RI & $\mathrm{C}$ & 3 & 1 \\
\hline Daressalaam + & RIV & $\ldots$ & $4 \dagger$ & $\ldots$ \\
\hline Napoli & RIII & $u$ & 3 & $\ldots$ \\
\hline Javiana & RII & $u$ & 1 & $\ldots$ \\
\hline Wangata & RII & $u$ & 11 & $52^{*}$ \\
\hline Portland & RIII & $u$ & 9 & 54 \\
\hline Pullorum & $\mathrm{RX}$ & C: SeCLI & 2 & $52^{*}$ \\
\hline
\end{tabular}

$\mathrm{C}$ or $u$ indicates conserved or unique IS200 pattern, respectively.

* Indicates plasmid hybridising to $s p v \mathrm{BC}$ probe.

$\dagger$ DNA does not digest with Pst I but four copies in digests with other enzymes.

$\ddagger$ These serotypes belong to ssp. II (salamae).

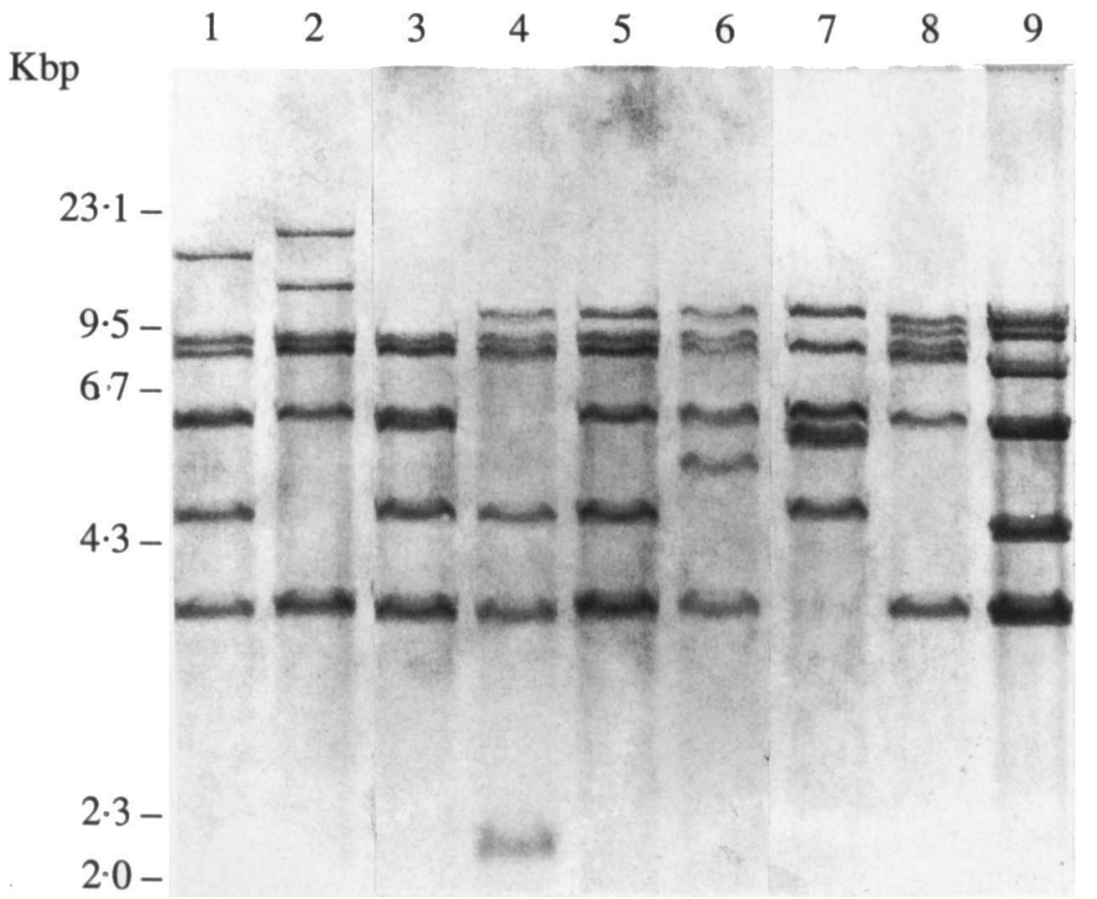

Fig. 3. Examples of 16S rRNA gene profiles showing genomic Southern blot ( $P v u l I)$ hybridised with 550-bp PCR amplicon internal to the 16S rRNA gene of serotype Dublin. Lanes contained: 1, Miami; 2, Panama; 3, Lomalinda; 4, Napoli; 5, Onarimon; 6, Pensacola; 7 , Pullorum; 8, Eastbourne; 9, Alabama. 


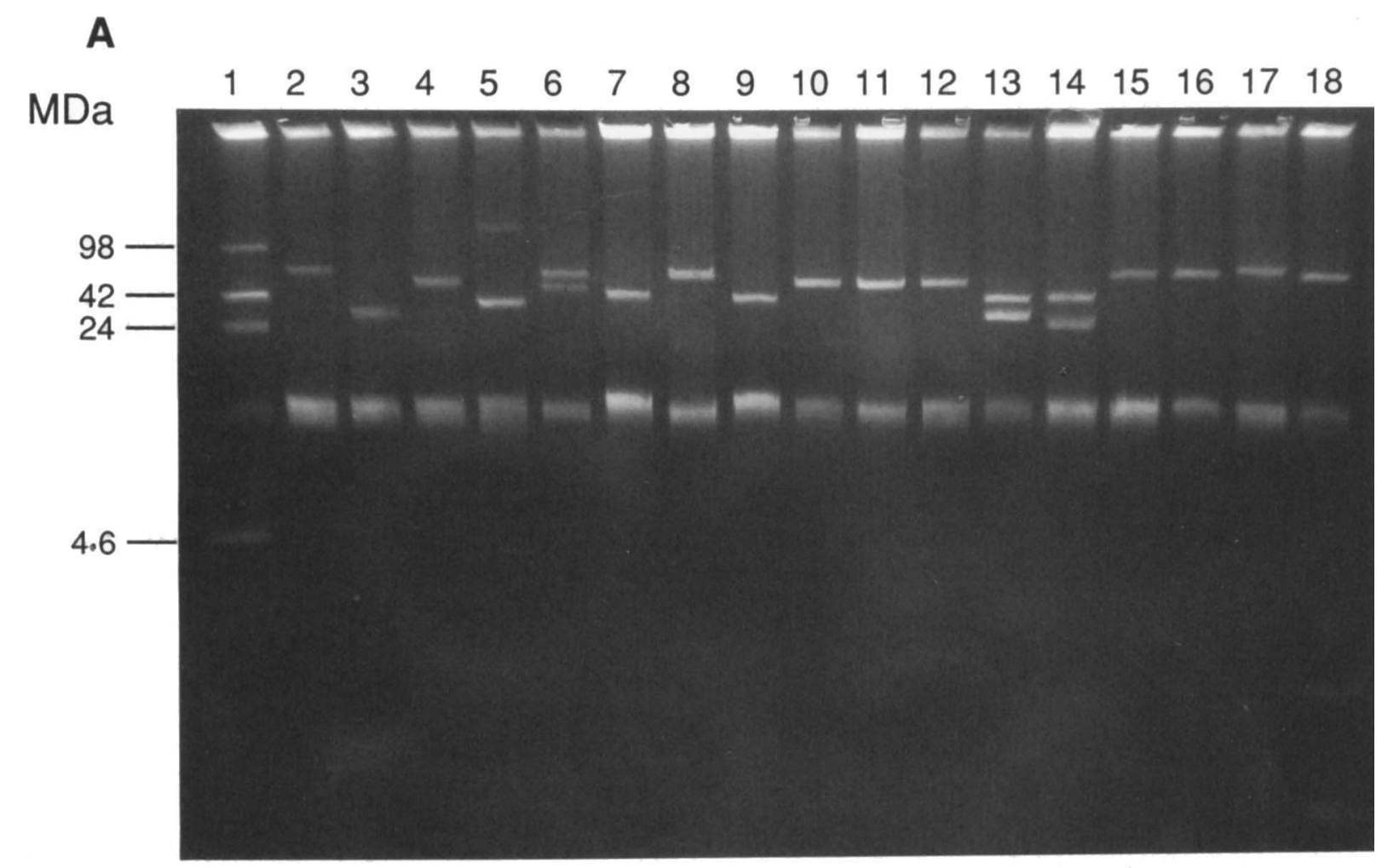

B

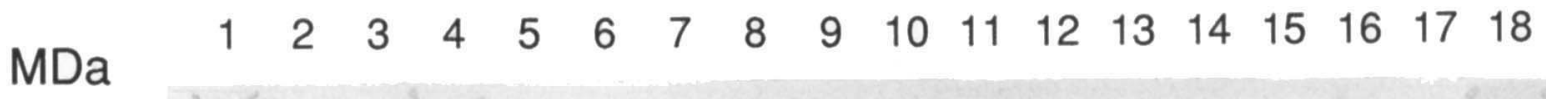

Fig. 4. Virulence plasmids in serogroup D1. A, Plasmid mini-preparations of E. coli 39R861, a plasmid mol. wt-marker strain, (lane 1) and of type strains of 15 Salmonella serotypes. Lane 2, Miami; 3, Lomalinda; 4, Alabama; 5, Eastbourne; 6, Israel; 7, Enteritidis PT4-E2 87; 8, Enteritidis PT11-E2019; 9, Blegdam; 10 and 11, Dublin; 12, Rostock; 13, Moscow; 14, Antarctica; 15, Clairbornei; 16, Wangata: 17. Portland; 18, Pullorum. B. Southern blots of gel in A, probed with spv $B C$ : homology with 11 plasmids was observed.

whilst serotype Wangata has recently been implicated in outbreaks of human salmonellosis in England and Wales. ${ }^{21}$ Like serotype Typhi, serotypes Lomalinda (dulcitol- and $d$-tartrate-negative), Portland (dulcitolnegative and raffinose-positive) are Wangata (nega- tive in glycerofuschin broth) and biochemically atypical. If the transposition rate of insertion sequences and their consequent mutagenic activity increase with copy number, the multiple chromosomal IS 200 insertions in these serotypes might have compromised their survival 
abilities, a situation reflected by the above metabolic deficiencies. They may have evolved either towards obligate host adaptation (e.g., Typhi) or towards rarity (e.g., Lomalinda). Again, serotypes Portland and Lomalinda may be host adapted, albeit to hosts not yet described, and, hence, as a result appear "rare".

Plasmids carrying spvBC-homologous regions ( $c f$. table II) and of very similar size to that of serotype Enteritidis (PT4) were detected in Antarctica, Blegdam and Moscow, serotypes which share its chromosomal IS200 profile, $\mathrm{SeCLI}^{12}$ (table II). On the other hand, Rostock contained a 50-MDa virulence plasmid, the same size as that of Dublin, and these two serotypes shared IS200 pattern SeCLIII, as found in Enteritidis (PT11), which is one of a number of Enteritidis phage types containing plasmids of this approximate size (59 MDa). The only serotype type strain sharing IS200 profile $\mathrm{SeCLI}$, but which carried a virulence plasmid of an unusual size, was Pullorum. The virulence plasmid of serotype Pullorum has been shown to be genetically distinct, belonging to an incompatibility group different from the 38-MDa plasmid of serotype Enteritidis and the 50-MDa plasmid of serotype Dublin. ${ }^{22}$ In serotypes Antarctica, Lomalinda and Wangata, spvhomologous plasmids were detected for the first time. The virulence plasmid of Wangata was of the same size (52 MDa) as that of Pullorum. Serotype Wangata has been reported to be a causative agent of poultryrelated outbreaks of human gastro-enteritis. ${ }^{21}$ The plasmid found in serotype Lomalinda is possibly the smallest virulence plasmid so far detected; only serotype Choleraesuis has been reported to carry one of such small size ( $33 \mathrm{MDa}){ }^{23}$

Almost half of the type strains of group D1 serotypes in this study contained neither virulence nor other plasmids, confirming that virulence plasmids are by no means ubiquitous in salmonellae, and that the plasmid-profiling approach to subtyping is not apvariants may be expected for a given serotype. IS200 plicable to many serotypes of Salmonella. Since many of these plasmid-free type strains, e.g., serotypes Typhi, Saarbruecken, Durban, Onarimon, Pensacola and Panama, contained $>5$ IS200 bands, chromosomal typing with IS200 should give a useful level of inter-strain discrimination within the serotype, as was shown for Typhimurium, ${ }^{5}$ providing a unified approach to genotypic subtyping. Except for Typhi, which can be phage-typed, subtyping schemes do not presently exist for any of these serotypes.

In this study we have addressed the general framework of IS200 patterns for a major serogroup by examining type-strain profiles. It has been shown that a given serotype tends to have a specific, related range of profiles and copy numbers of IS200.5 Thus, the profiles reported here do indicate what range of profiling can be photographically or diagrammatically represented in a band-matching database, facilitating the comparison of data between laboratories - an important consideration for epidemiology. Where the number of IS200 bands is moderate to high, the chromosomal types so defined are consistent with the theoretical considerations defining clonality, ${ }^{24}$ and may be more definitive than phenotypic types for medico-legal aspects of salmonellosis. Results obtained with IS6110 typing of Mycobacterium tuberculosis, recently adopted internationally as a standard method, ${ }^{25}$ confirm the applicability and reliability of this approach in epidemiological typing.

N.P. was the recipient of an NCTC British Industries Research Fund Studentship.

\section{References}

I. Popoff MY, Bockemühl J, McWhorter-Murlin A. Supplement 1991 (no. 35) to the Kauffmann-White scheme. Res Microbiol 1992; 143: 807-811.

2. Grimont F, Grimont PAD. Ribosomal ribonucleic acid gene restriction patterns as potential taxonomic tools. Ann Institut Pasteur (Microbiol) 1986; 137B : 165-175.

3. Lam S, Roth JR. IS200: a Salmonella-specific insertion sequence. Cell 1983; 34: 951-960.

4. Lam S, Roth JR. Structural and functional studies of insertion element IS200. J Mol Biol 1986; 187: 157-167.

5. Stanley J, Baquar N, Threlfall EJ. Genotypes and phylogenetic relationships of Salmonella typhimurium are defined by molecular fingerprinting of IS 200 and $16 \mathrm{~S} \mathrm{rrn} \mathrm{loci.} J \mathrm{Gen}$ Microbiol 1993; 139, 1133-1140.

6. Norel F, Coynault C, Miras I, Hermant D, Popoff MY. Cloning and expression of plasmid DNA sequences involved in Salmonella serotype typhimurium virulence. Mol Microbiol 1989; 3: 733-743.

7. Williamson CM, Baird GD, Manning EJ. A common virulence region on plasmids from eleven serotypes of Salmonella. $J$ Gen Microbiol 1988; 134: 975-982.

8. Gulig PA. Virulence plasmids of Salmonella typhimurium and other salmonellae. Microb Pathog 1990; 8: 3-11.

9. Helmuth R, Stephan R, Bunge C, Hoog B, Steinbeck A, Bulling E. Epidemiology of virulence-associated plasmids and outer membrane protein patterns within seven common Salmonella types. Infect Immun 1985; 48: 175-182.

10. Roudier C, Krause M, Fierer J, Guiney DG. Correlation between the presence of sequences homologous to the vir region of Salmonella dublin plasmid pSDL2 and the virulence of twenty-two Salmonella serotypes in mice. Infect Immun 1990; 58: 1180-1185.

11. Catalogues of the National Collections of Type Cultures and Pathogenic Fungi, 7th edn. London, Public Health Laboratory Service. 1989.

12. Stanley J, Jones CS, Threlfall EJ. Evolutionary lines among Salmonella enteritidis phage types are identified by insertion sequence IS200 distribution. FEMS Microbiol Lett 1991 ; 82: 83-90.

13. Kado CI, Liu S-T. Rapid procedure for detection and isolation of large and small plasmids. J Bacteriol 1981: 145: 1365-1373

14. Wilson K. Preparation of genomic DNA from bacteria. In: Ausubel FM, Brent R, Kingston RE et al. (eds) Current protocols in molecular biology, vol 1. New York, Wiley. 1990: 2.4.1-2.4.5.

15. Gibert I, Carroll K, Hillyard DR, Barbé J, Casadesus J. IS200 is not a member of the IS 600 family of insertion sequences. Nucleic Acids Res 1990; 19: 1343.

16. Brosius J, Palmer ML, Kennedy PJ, Noller HF. Complete nucleotide sequence of a $16 \mathrm{~S}$ ribosomal RNA gene from Escherichia coli. Proc Natl Acad Sci USA 1978; 75: 4801-4805.

17. Ezquerra E, Burnens AP, Frith K, Costas M. Stanley J. Molecular genotype analysis of Salmonella bovismorbificans. Mol Cell Probes 1993; 7: 45-54. 
18. Smith NH, Beltran P, Selander RK. Recombination of Salmonella phase 1 flagellin genes generates new serovars. $J$ Bacteriol 1990; 172: 2209-2216.

19. Selander RK, Smith NH, Li J et al. Molecular evolutionary genetics of the cattle-adapted serovar Salmonella dublin. $J$ Bacteriol 1992; 174: 3587-3592.

20. Li J, Smith NH, Nelson K et al. Evolutionary origin and radiation of the avian-adapted non-motile salmonellae. $J$ Med Microbiol 1993; 38: 129-139.

21. Anonymous. Communicable Disease Report 2. PHLS/CDSC Publications. 1992: 133, 149.

22. Ou JT, Baron LS, Dai XY, Life CA. The virulence plasmids of Salmonella serovars typhimurium, choleraesuis, dublin, and enteritidis, and the cryptic plasmids of Salmonella serovars copenhagen and sendai belong to the same incompatibility group, but not those of Salmonella serovars durban, gallinarum, give, infantis and pullorum. Microb Pathog 1990; 8: 101-107.

23. Kawahara K, Haragucki Y, Tsuchimoto M, Terakado N. Danbara $\mathrm{H}$. Evidence of correlation between 50-kilobase plasmid of Salmonella choleraesuis and its virulence. Microb Pathog 1988; 4: 155-163.

24. Ørskov F, Ørskov I. Summary of a workshop on the clone concept in the epidemiology, taxonomy, and evolution of the Enterobacteriaceae and other bacteria. $J$ Infect Dis $1983 ; 148$ : 346-357.

25. Van Embden JDA, Cave MD, Crawford JT et al. Strain identification of Mycobacterium tuberculosis by DNA fingerprinting: recommendations for a standardized methodology. J Clin Microbiol 1993; 31 : 406-409. 